\title{
Leave to Appeal and Leave to Commence Judicial Review in Canada's Refugee-Determination System: Is the Process Fair?
}

\author{
IAN GREENE* AND PAUL SHAFFER†
}

The purpose of this study is to determine whether refugees and other persons who are applying for leave to appeal a decision of the Convention Refugee Determination Division of the Canadian Immigration and Refugee Board, a decision of the Appeal Division of the Immigration and Refugee Board, or to commence an action for judicial review have a relatively equal chance to convince theFederal Court of Appeal of the merits of their applications.

The significance of this study can be appreciated only in relation to the history of Canada's refugee determination legislation. In April 1985, the Supreme Court of Canada declared that a part of Canada's refugee determination process outlined in the Immigration Act was contrary to the Canadian Charter of Rights and Freedoms. The system then in effect allowed some refugee claimants to be deported from Canada without ever having had an oral hearing before a court or tribunal. The Court declared that the absence of a guarantee of at least one oral hearing for refugee claimants violated section 7 of the Canadian Charter of Rights and Freedoms ('everyone' has the right to 'life, liberty and security of the person' unless 'deprived thereof ... in accordance with the principles of fundamental justice') and section 2(e) of the Canadian Bill of Rights, which provides a right to a 'fair hearing in accordance with the principles of fundamental justice for

* Associate Professor of Political Science, York University, Toronto.

$\dagger$ Doctoral candidate in political science at the University of Toronto. 
the determination of [a person's] rights and obligations.' Both 'fundamental justice' and a 'fair hearing' require at least one oral hearing before an impartial tribunal.'

Canada's Department of Employment and Immigration had been totally unprepared for such a decision, and it was not until May 1987 that legislation prescribing a new refugee-determination process was introduced into the House of Commons. In the meantime, the old system remained in effect except that every refugee claimant had a right to an oral hearing. The refugee determination system became hopelessly backlogged, and in reaction the government felt under pressure to develop a new refugee determination procedure which would prevent future backlogs by discouraging refugees from applying for refugee status from within Canada; the processing of refugee applications from abroad was the preferred route of the Department of Employment and Immigration. The 1987 legislation, which was contained in Bill C-55, in its original form would have given persons claiming refugee status in Canada only seventy-two hours to establish a 'credible basis' for their claim or face deportation. Persons arriving from a 'safe third country,' a term not defined in the legislation, would not even be able to apply for refugee status.

Bill C-55 was vehemently denounced by the Canadian Bar Association, refugee support groups, all of the major churches and the Canadian Jewish Congress because of its potential violation of human rights. The government began to back away from the legislation until in the summer of 1987 a ship arrived off the coast of Nova Scotia and put ashore 174 East Asians, mostly Sikhs, who claimed refugee status. Part of the reason for their coming in this bizarre fashion was because of the fear that they would never be able to apply for refugee status in Canada, since most had travelled through what might be considered a 'safe third country.' This event caused a public reaction to refugee claimants which gave the government the ammunition it needed to push Bill C-55 through the House of Commons. In addition, the government introduced companion legislation, Bill C-84, which gave Canadian authorities the power to apprehend ships suspected of carrying refugee claimants to Canada on the high seas. Bills C-55 and C84 were stalled in the Senate until the summer of 1988, and after negotiation between the two houses some of the harsher provisions of both bills were softened.

The bills eventually passed, and the present system of refugee determination in Canada came into effect on January 1, 1989

\footnotetext{
I Singh et al. o. Minister of Emplogment and Immigration, [1985] 1 SRC 177. Three of the six judges who finally decided this case based their decision on the Charter, while the other three based their decision on the Canadian Bill of Rights.
} 
although the 'safe third country' provisions in Bill C-55 have not, to date, been implemented. The avowed intent of the new legislation was to maintain Canada's commitment to the protection of genuine refugees while controlling a perceived 'widespread abuse' of the system by bogus claimants and 'those who assist in their illegal entry.' In effect, the legislation sought to reduce the number of illegitimate refugee claims by preventing ineligible claimants from remaining in Canada for the (often lengthy) duration of their claim, and by expeditiously adjudicating refugee claims in Canada. As one leading analyst commented, 'overall, the intention is to deter people from making claims. ${ }^{3}$ On the other hand, it was hoped by the drafters of the legislation that persons who succeeded in entering Canada to make a refugee claim would be dealt with expeditiously so that bona fide refugees could quickly be identified and given permanent residence status, and that bogus claimants would swiftly be deported.

The new inland refugee determination system in Canada proceeds as follows. To begin with, refugee claimants may be allowed to remain in Canada on humanitarian and compassionate grounds. In most cases this means that the claimant must be married to someone legally resident in Canada, and must prove that the marriage is not one of convenience. The great majority of refugee claimants do not benefit from the humanitarian and compassionate grounds review and must proceed to a two-stage inquiry process in order to remain in Canada. The first stage, the initial inquiry, is presided over by an adjudicator - and a member of the Convention Refugee Determination Division (CRDD) of the Immigration and Refugee Board (IRB). The claimant must satisfy eligibility criteria and demonstrate a credible basis for his/her claim. ${ }^{4}$ If a negative decision is reached by both presiding members on either issue, the claimant's only recourse is to apply to the Federal Court of Appeal for leave to commence judicial review proceedings. $^{5}$

If either presiding member is satisfied on both issues, the claim proceeds to the second stage of the process, a full hearing before two members of the CRDD who were not involved in the initial inquiry. If a positive decision is reached by either member at the full hearing, the claimant is declared a Convention refugee and eligible for landing in

2 See Section 2.1 of Bill C-55.

- Nash, A., International Refuge Pressures and the Canadian Public Poligy Response, (Ottawa: Institute for Research on Public Policy, January 1989), 31.

4anada, Immigration Act, s. 46.01. When the new system was originally unveiled, government spokespersons estimated that the first stage could be completed within from three to seven days. (Nash, Intemational Refuge Pressures, 32.) In practice, it has frequently taken months or even years for first-stage completion; see Law Reform Commission of Canada, The Detemination of Refuges Status in Castada: A Reviaw of the Procedure, Preliminary Study: A Consultatios Doament, 1 Feb. 1991,63 ff.

${ }^{3}$ Canada, Immigration Act, s. 82.1. 
Canada. If a negative decision is reached by both presiding members, the claimant's only recourse is to apply for leave to appeal to the Federal Court of Appeal. ${ }^{6}$ If either type of leave application (for judicial review after the first stage, or for appeal after the second stage), is rejected, there is no recourse to appeal the negative leave decision to a higher judicial authority. ${ }^{7}$

One of the major criticisms which has been levelled at this twostage process concerns the competence of some of the approximately 210 members of the CRDD. Many are political appointments, and few have legal training. ${ }^{8}$ According to research conducted by the Law Reform Commission of Canada, although ' $t$ the majority of members [of the GRDD] do seem sympathetic to the plight of refugees in general' and 'there did not appear to be a systematic attitudinal problem,' [s] everal members [of the CRDD in Toronto] were identified [by several counsel and Refugee Hearing Officers] as outspoken, frequently badgering witnesses, reactionary, disputatious, secretive, biased, unpleasant, contemptuous and cynical. ${ }^{99}$ Another criticism is that a number of lawyers representing refugee claimants do not have a firm enough grasp either on how the current system operates or on refugee law so as to represent their clients effectively. ${ }^{10}$ In Vancouver, for example, ' $[\mathrm{m}]$ ost counsel referred . . . to the first level hearings ... are ... juniors. Training in the procedures followed at refugee hearings is normally gained on the job, and no immigration or refugee law courses are available." 'Especially because of these factors, it is essential that refugee applicants have a reasonable access to appeal.

However, in order to ensure that unsuccessful claims are disposed of quickly and not tied up for months or years on appeal, leave provisions were developed in the Immigration Act (which cover either leave to appeal or leave for judicial review) which are exceedingly strict. At either of the two stages of the refugee determination process, leave of a single judge of the Federal Court Appeal is required for

6 Ibid., s. 82.3 (1). This appeal process does not apply where the CRDD has found a claim lacking a credible basis, in which case there is no further avenue of appeal (ibid, 3. 82.3 (2)); judicial review, however, continues to be available on the same grounds. See Salibian o. Minister of Emploment and Immigration [1990] 3 F.C. 250.

7 Ibid., ss. 82.2(2), 84.1.

B See Law Reform Commission, The Detemination of Refugee Status in Canada, 37 fr. The Immigratzon $\mathrm{Act}$, s. 61(3), requires that at least 10 per cent of full-time permanent members of the CRDD be lawyers of at least five years standing at a provincial bar. Sec. 59 limits the number of full-time permanent members to 65 . According to our research, the proportion of qualified lawyers among the 65 or fewer members varied between about 11 and 20 per cent in 1990 and 1991. Nearly three-quarters of the full-time members of the CRDD, however, are temporary members. The proportion of lawyers with five years standing among the full complement of fulltime members of the CRDD varied between 8 and 12 per cent during 1990 and 1991. According to the 1990 Ammal Report of the Immigration and Refugee Boand, there were 248 full-time CRDD members at the end of 1990 .

9 Ibid., 37.

${ }^{10}$ Ibid., $44 \mathrm{fT}$.

11 Ibid., 45. 
judicial review or appeal of negative decisions on refugee claims. Applications for leave must be filed with the Federal Court of Appeal within fifteen days, and the leave application must be heard within another fifteen days although Federal Court of Appeal judges have discretion to grant extensions to these deadlines. ${ }^{12}$ The deadlines normally leave lawyers little time to assemble quality factums on the law and the facts. As well, obtaining transcripts of the first- or secondlevel inquiry in time for the leave application can present a serious problem. There are no statutory criteria within the Immigration Act to guide the judges when making decisions about granting leave, and there is no requirement that reasons accompany negative leave decisions. ${ }^{13}$

The present study examines the manner in which the leave provisions of the Immigration Act have been applied by the Federal Court of Appeal judges. A uniform and just application of the law is particularly important in cases of refugee determination because of the severe human consequences which may result if the law is misapplied. Further, failure to ensure that the law is consistently applied may violate guarantees of fundamental justice in Section 7 of the Canadian Charter of Rights and Freedoms and the right to a fair hearing in accordance with the principles of fundamental justice under Section 2(e) of the Canadian Bill of Rights.

The study of dispositions covers leave applications which were filed in the Federal Court of Appeal under Section 82.1 (applications for judicial review after a refugee claimant fails on credible basis grounds at the first level of the refugee determination process), Section 82.3 (applications for leave to appeal the decision of the IRB after a refugee claimant fails at the full hearing stage of the refugee determination process), or Section 83 of the Immigration Act (applications for leave to appeal a decision of the Appeal Division of the IRB on a question of law or jurisdiction) between January 11990 and December 311990. Most of the applications were disposed of in 1990, although $23 \%$ were decided early in 1991.

\section{Methodology}

In early April 1991, a systematic random sample of 611 cases-a sample more than sufficiently large to meet social science standards for a study of this kind-was selected from the approximately two thousand applications for leave to appeal filed in 1990. The files were

\footnotetext{
12 Immigration Act, ss. 82.1 (3), (5) and (6); 82.3 (4), (5) and (6); and 83 (2), (3) and (4).

13 In principle, the criterion is the existence of a serious issue to be heard. In practioe, many different criteria are applied. (See Law Reform Commission of Canada, The Determination of Refuget Status in Canada. Preliminan Study, 11, 34-35.
} 
stored in chronological order of filing in boxes in the Federal Court of Appeal office in Ottawa; every third file was pulled to generate the sample. This method of generating a representative sample is credible and widely used in the social sciences. Because the sample is large and representative, inferences can be made about the leave cases filed in 1990 in general with little fear that the sampling procedure may have accidentally resulted in the selection of a higher proportion of weak cases for some of the judges. The degree of accuracy of these inferences, which turns out to be extremely high, is indicated by the statistical tests reported below.

Files which were disposed of due to lack of materials (a missing factum or affidavit) were eliminated from the sample because they did not involve a judge having to make a substantive decision. Whenever a file with missing materials was encountered, the research assistant would substitute the next file in the box for it.

The following twelve Federal Court of Appeal judges made decisions on leave applications from applicants during 1990:

The Honourable Frank Iacobucci (then Chief Justice of the Federal Court of Canada)

The Honourable Louis Pratte The Honourable Arthur Stone

The Honourable D.V. Heald The Honourable Mark MacGuigan

The Honourable John Urie The Honourable Alice Desjardins

The Honourable Patrick Mahoney The Honourable Robert Décary The Honourable Louis Marceau The Honourable Allen Linden The Honourable James Hugessen

\section{Results of Analysis}

Of the cases filed during 1990, the judges decided an average of 51 cases each. The number of cases decided by each judge ranged from a low of 21 decisions to a high of 91 . In total, leave was granted in $25 \%$ of the cases ( 153 cases of 608 ).${ }^{14}$ Reasons were given in 68 of the cases, or $11.1 \%$. Reasons were given in $14 \%$ of the cases in which leave was not granted, and in only $3 \%$ of the cases in which leave was granted. None of the decisions involved an oral hearing.

Thirty-four percent of the applications (208) were filed under Section 82.1 of the Immigration Act (application for judicial review after applicant's failure at first level). Sixty-four percent (388) were filed under Section 82.3 (application for leave to appeal after applicant's failure at full hearing level), and two percent (12) were filed under Section 83 (application for leave to appeal from the Appeal Division of the IRB on a question of law).

14 Information about the disposition was missing from three of the files. 


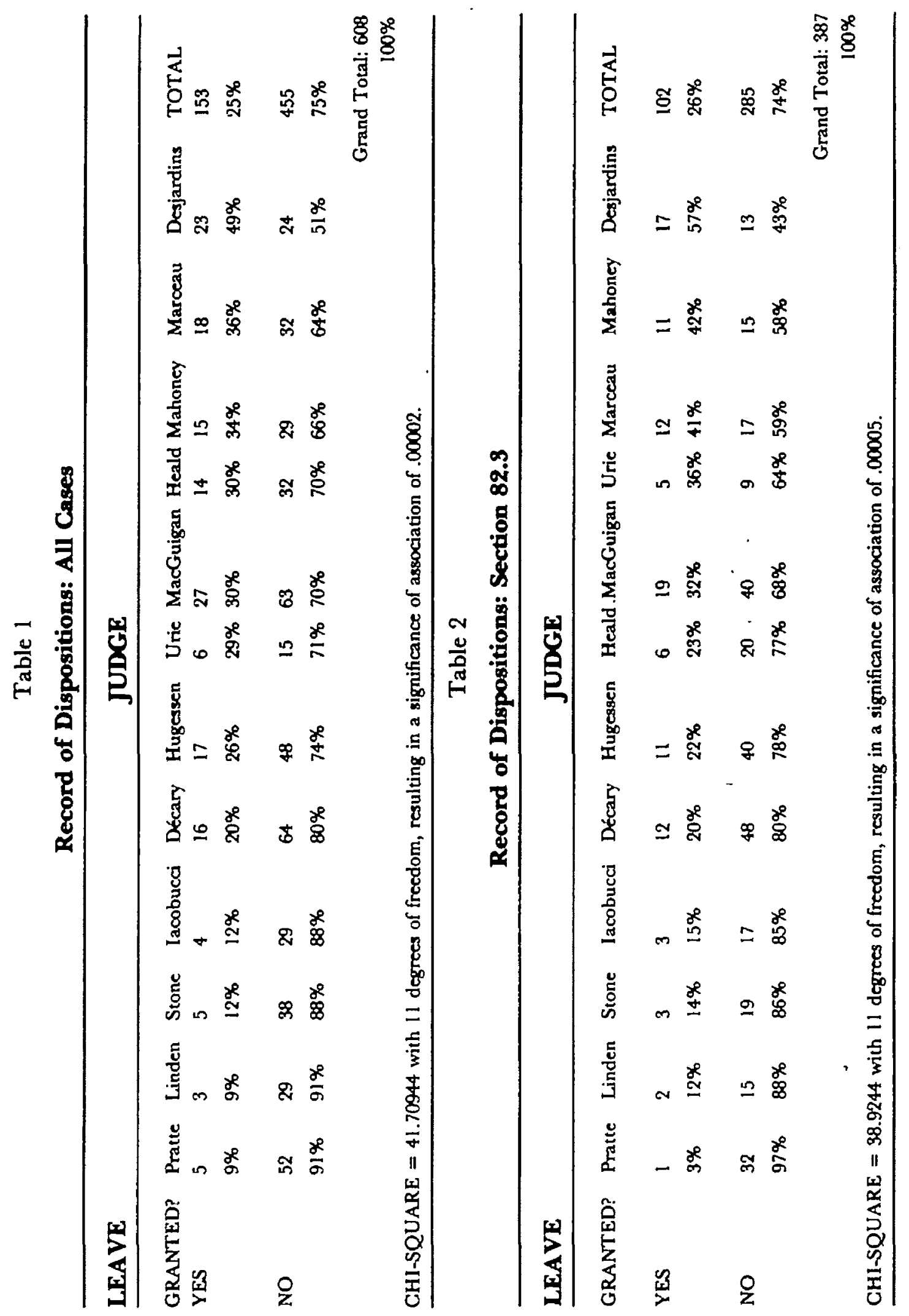


The individual judges' decisions on whether or not to grant leave with regard to all three sections being examined are shown in Table 1. Table 2 shows the judges' decisions for sections 82.3 only. ${ }^{15}$

The most common statistical test used in this analysis is a test for significance of association based on the chi-square statistic. For those unfamiliar with this procedure, an association is considered to be statistically significant if two variables (such as 'judge' and 'decision regarding leave to appeal') which are compared in a contingency table (such as the two tables shown above in which leave to appeal decisions are shown as contingencies of the individual judges on the Court) have cell counts distributed in such a way that there is very little possibility that they could have occurred at random. For example, Table 1 shows that on average, the Federal Court of Appeal approved $25 \%$ of the applications it received for leave to appeal under sections 82.1, 82.3 and 83 of the Immigration Act. If each of the judges in the court approved roughly $25 \%$ (for example, $20 \%$ to $30 \%$ ) of the applications they received for leave to appeal, then it could be said that there is no statistically significant association between the variable 'judge' and the variable 'decision regarding leave to appeal.' If, however, the leave to appeal records of the individual judges are widely different, then the two variables are considered to be 'associated;' in other words, in this case leave to appeal decisions are in some way associated with the characteristics of the individual judges.

In the social sciences, two variables are not generally considered to be associated unless the chi-square statistic indicates that there is less than a five per cent chance that the variables are not associated. Therefore, if the level of significance is .05 (five per cent) or less, it can be accepted that two variables are associated. The smaller the level of significance, the greater the confidence that the variables are indeed associated.

With regard to the tables above, the chi-square test indicates that there is a statistically significant association between individual judges and the outcome of leave applications. For Table 1, the level of significance is .00002 , which means that given an infinite number of tables configured something like Table 1 , we would be correct in concluding that the two variables are associated 99,998 times out of 100,000 . Concerning applications under Section 82.3 (Table 2), the significance level is .00005 , which means that we would be correct in inferring an association 99,995 times out of 100,000 . It should be noted that confidence levels this high are very rarely encountered in social science research. ${ }^{16}$

\footnotetext{
13 The number of cases for Section 82.1 and Section 83 were too low to permit a meaningful separate analysis of decisions for these sections.

16 As well, a statistical test for strength of association, 'Cramer's V,' was applied to the tables. The resulting value was .262 for Table 1 and .317 for Table 2 . When Cramer's $V$ is .25 or greater, the association is considered to be moderately strong.
} 
It could be argued, however, that factors other than the judges' predispositions might explain the associations shown in Tables 1 and 2 , and these factors must be considered before a firm conclusion can be drawn that the judges' predispositions have something to do with the outcome of leave to appeal applications. For example, it is possible that some judges have ended up with a much greater proportion of weak cases in their caseloads than other judges because of the method used to assign cases to judges.

The Federal Court of Appeal judges receive leave applications on a weekly rotation basis; therefore, it is unlikely that some judges would consistently receive weaker cases than others. However, the registrar's office of the Federal Court of Appeal receives leave to appeal applications in weekly batches. If law firms file a number of leave applications at once, during any particular week the cases which the judge on rotation receives might be disproportionately composed of cases from firms which specialize in representing applicants from specific countries. It is possible therefore that by chance, some judges might receive a higher proportion of cases from applicants from countries which have a poorer human rights record than others. Of course, over time such deviations from random assignment of cases would get ironed out, but in case a year of rotations is not sufficient to produce close to a random assignment of cases to judges, the possible impact of this factor on the outcome of leave to appeal decision will be investigated.

In order to test for an association between two factors, the numbers in the cells of the contingency table must be sufficiently large. ${ }^{17}$ In order to achieve this criterion with regard to the contingency table involving 'judge' and 'country of origin of leave applicants,' it was necessary to group the countries of origin of the leave applicants into the following five categories: Africa, Latin America, Europe, Asia and the Pacific Islands, and the Middle East. It was found that there was an association between country of origin of the leave applicants and the variable 'judge' which was significant at the .01 level (meaning that there is one chance in 100 that no association exists between these variables). It was therefore necessary to test for an association between 'judge' and 'decision regarding leave to appeal' controlling for the effects of the variable 'country of origin of applicant.' To control for 'country of origin of applicant,' a contingency table was constructed for 'judge' and 'decision regarding leave to appeal' within each of the five grouped categories of 'country of origin.' It was found that the association between 'judge' and 'decision regarding leave to appeal' remained within each of the five categories of 'country of origin' at at

\footnotetext{
17 As a general goal, no more than about $15 \%$ of the 'expected' cell frequencies in a contingency table should be less than 5 . Expected cell frequencies are those that would result if there is no association between two variables.
} 
least the .02 level. ${ }^{18}$ This analysis indicates that even though the judges did not receive quite the same proportion of cases from five regions of the world, this anomaly does not explain away the moderately strong association between 'judge' and 'decision regarding leave to appeal.'19

Another way of testing 'country of origin of applicants' as an explanation for the variation in 'decision regarding leave to appeal' is to group the countries of the applicants according to the success rate of refugee applicants rather than to group the countries of origin geographically. The countries of origin of the leave to appeal applicants were accordingly divided into three categories: those most likely to be successful at the second (full hearing) stage of the refugeedetermination process, those least likely to be successful, and those with a moderate success rate. ${ }^{20}$ Statistical analysis showed that there was no association between 'country of origin of applicants' grouped according to success rate and 'decision regarding leave to appeal.'21 Therefore, it can be concluded that the success rate of the applicants' country of origin at the second stage of the refugee determination process has nothing to do with the chances of success of applicants for leave to appeal in the Federal Court of Appeal. Again, this reinforces our conclusion that the differences among the judges in the proportion of leave applications from applicants of various countries cannot explain away the association between 'judge' and 'decision regarding leave to appeal.'

10 In order to meet the minimum expected cell count criterion, the variable 'judge' was divided into three categories: the four 'toughest' judges in Table 1, the five most 'liberal' judges, and the three judges in between. The association between 'judge' and 'decision regarding leave to appeal' was significant at the .02 level within the African and Latin American group of countries, and at the .00002 level within the Asia-Pacific Islands group. With this grouping of judges, there was no significant association within the other two country categories, Europe and the Middle East. However, when the judges within each of these latter two country groups were re-grouped into 'tough' and 'liberal' judges with regard only to these two categories, there was a significant association between 'judge' and 'decision regarding leave to appeal' at the .0005 level in both country groups. This analysis suggests that the influence of the judges' own predispositions may be different depending on the country involved. This finding is hardly surprising, given previous research into the relation between judicial predispositions and decision-making which indicates that judicial predispositions are issue-dependent. Sce, for example, Neil Tate and Panu Sittuwong, 'Explaining the Decision-Making of the Canadian Supreme Court, 1949 1985: Extending the Personal Attributes Model Across Nations,' Joumal of Politics 51 (1989).

19 This conclusion is reinforced by the fact that there is no significant association between 'decision regarding leave to appeal' and 'country of origin of applicant.'

20 Information on success rates at the second (full hearing) stage of the refugee-determination process was obtained from the July 31, 1991 news release of the Immigration and Refugce Board. Countries producing refugees with a low rate of success at the second stage were defined as those with an acceptance rate of $50 \%$ or lower. Those countries with a moderately-high success rate were defined as having a success rate of between $50 \%$ and $67 \%$. Those countries with a high success rate were defined as having a success rate of higher than $67 \%$.

21 Significance $=.295$. 
It will be recalled that all of the cases in the sample being analyzed were filed in 1990, but that some were decided during the first quarter of 1991. This means that the decisions were distributed among five quarter-year periods. A variable was created dividing the cases into the five quarter-year periods, and a contingency table was constructed with the variables 'decision regarding leave to appeal' and 'time period.' The association between these two variables was significant at the .003 level. (The success rate of applicants in each quarter was as follows: $35 \%, 52 \%, 36 \%, 35 \%$ and $15 \%$. These varying success rates are not significantly associated with the country of origin of the applicants.) In order to ensure that the association between 'judge' and 'decision regarding leave to appeal' cannot be explained by the variable 'time period,' the association between 'judge' and 'decision regarding leave to appeal' was tested within each of the five quarteryear periods. In the second to fifth quarter-years, the associations between 'judge' and 'decision regarding leave to appeal' were statistically significant; there were not enough decisions (38) during the first quarter-year to allow for statistical testing. ${ }^{22}$ What this analysis shows is that even though the success rate of applicants varied over the timeperiod studied, this variance does not explain the association between 'judge' and 'decision regarding leave to appeal. ${ }^{\text {,3 }}$

\section{Conclusions}

The conclusion is inescapable that an association exists between individual judges on the Federal Court of Appeal and the rate of success of applicants for leave to appeal. The mere existence of this association, however, does not explain why that association exists. One possible explanation is that the criteria for granting leave in the legislation are unclear, so that the judges' approach to deciding the applications are quite understandably widely different. As well, because reasons are rarely given for granting or denying leave and there is no appeal from the leave decision, there are few objective

22 The significance levels for the second quarter-year was .055 ; for the third, .0025 ; for the fourth, .0016; and for the fifth, .0073 .

25 To further test the effects of the variables 'judge,' 'country of origin (geographic)' and 'time period' on the dependent variable 'decision regarding leave to appeal,' an analysis of variance was conducted using these variables. This analysis showed that although 'judge,' 'time period' and 'country of origin' all help to explain the configuration of the variable 'decision regarding leave to appeal,' 'judge' was by far the variable with the greatest explanatory value, followed by "time period' and then 'country of origin,' This analysis confirms the results of the analysis above which concludes that there is a moderately strong association between 'judge' and 'decision regarding leave to appeal,' (Cramer's $V=.317$ ) as well as weaker associations between 'time period' and 'decision regarding leave to appeal' (Cramer's $V=.163$ ), and between 'country of origin (geographic)' and 'decision regarding leave to appeal' (Cramer's V =.104). 
standards around which a case law could develop which could mitigate in favour of a greater uniformity of the application of the law.

It is arguable, therefore, that applicants for leave under sections 82.1, 82.3 and 83 of the Immigration Act are denied fundamental justice when applying for leave to appeal in the Federal Court of Appeal because they do not have an equal chance of convincing the judge that their application for leave ought to be granted. 'A fundamental if formal principle of justice requires that like cases be treated alike. If discrepancies or deviations emerge within any decision-making system, then, in the absence of evidence of relevant considerations that would explain such variations, an inherent injustice will be inferred. ${ }^{24}$ Those applicants appearing before Madame Justice Desjardins, for example, are 5.4 times more likely to succeed in their applications for leave to appeal, than those appearing before $\mathrm{Mr}$. Justice Pratte.

During the past several decades, social science research has demonstrated time and again that different judges will decide similar cases differently, ${ }^{25}$ although the degree of difference discovered in this present study is rare. Such findings do not cast aspersions on judges; social seience research has shown that judges generally do their level best to decide cases impartially. ${ }^{26}$ However, judges are human beings, and where the law is unclear, they will vary in their approach to dispositions for similar cases. Appeal and judicial review procedures are provided to ensure that the variations among judges do not prevent persons from obtaining justice, and appellate judges generally sit in panels in order to mitigate the effects of individual judicial predispositions. ${ }^{27}$ Procedures which unnecessarily limit appeals and judicial review, such as those to be found in Sections 82.1,82.3 and 83 of the Immigration Act, may therefore violate the guarantee of fundamental justice in Section 7 of the Canadian Charter of Rights and Freedoms and the right to a fair hearing guaranteed by the Canadian Bill of Rights. ${ }^{28}$

24 Law Reform Commission of Canada, The Determination of Refuges Status in Carada, 119.

25 See, for example, John Hogarth, Sentencing os a Human Process (1971).

26 See PeterMcCormick and Ian Greene, Judges and Judging: Inside the Canadian Judicial System (Toronto: Lorimer, 1990), Chapter 1.

27 In a study of the Ontario Court of Appeal, Carl Baar, Ian Greene, Peter McCormick and Martin Thomas found that panels of judges had a 'levelling' effect on the tendencies of individual judges in criminal cases. When the judges' individual records were examined, in the context of all the panels they sat on, it was found that there was a slight tendency for some judges to decide more often in favour of the accused than other judges. When these same judges were studied in the context of specific panel decisions, their individual tendencies were always modified in the direction of the average tendencies of the judges on the panel. See McCormick and Greene, Judges and Judging: Iaside the Canadian Judicial System, above note 26, 256.

28 According to anonymous interviews with three senior court officials in British Columbia, the Court of Appeal experimented with having singte judges in chambers hear applications for leave to appeal sentences in 1987 and 1988 . Before this time, leave applications were heard by 
It is ironic that the legislation which was drafted with a view to meeting the requirements for fundamental justice and a fair hearing in the Singh decision may falter at the same barrier as the old legislation. Although the post-1989 refugee-determination procedure does provide all refugee claimants with an oral hearing, the legislation overlooks another very important aspect of a fair hearing: reasonable and fair access to appeal.

panels of three judges. The experiment was eventually abandoned for two reasons. First, there was a discrepancy among the judges concerning the rate at which they granted leave. According to one court official, some judges granted leave in almost every case, while others were very strict. This discrepancy was felt to be unfair to the applicants. Second, there were some administrative problems with the motions system. The Court returned to having the leave applications heard by three-judge panels. 